\title{
Polybius the Non-hostage
}

\author{
By Paavo Roos*
}

\begin{abstract}
It is a common notion that Polybius was a hostage in Rome, but was it really so his position was looked upon? Has any preserved ancient author used the term for him? No, in fact none of them has called him so. The part where Polybius himself described his and his colleagues' transport to Rome is not preserved, and he gives no term for his position. Of the other historians who deal with the sequel of the Macedonian war none narrates the event in their preserved parts, and nobody uses the word hostage. The narrative of the event is instead given by Pausanias in his description of Achaea, who also does not use the word hostage (in fact he seldom does). So technically it is quite wrong to use the word hostage of Polybius. But of course Polybius may have felt as a hostage even if he does not use the word about his status. In fact many persons in Antiquity have metaphorically described themselves or their relatives as hostages, so in that respect the word can be used in a wider sense.
\end{abstract}

Even if common knowledge concerning hostages in Antiquity is rather small there is at least one fact that seems to belong to it. If you mention hostages in Antiquity as a neglected subject you will often hear the statement: 'Polybius was a hostage in Rome, was he not?' Well, perhaps he was, it is sometimes reported so in modern literature, ${ }^{1}$ but what about ancient literature? It is quite certain that he was brought to Rome together with a thousand other members of the Achaean League after the Romans had defeated the Macedonians, and detained there. But from where do we know it? Which ancient authors give us the information? Do they tell us why and how it was decided that Polybius should be brought to Rome? Does any of the ancient authors use the word hostage about him?

The event in question took place in the year after the war between the Romans and the Macedonian king Perseus, which ended in 168 B.C. The previous decennia had seen successful Roman wars against Carthaginians, Macedonians, Aetolians and Seleucids, all of which had brought numerous hostages to Rome, but this war was different. The aim of the treaties after the previous wars had been the keeping of relations with inferior and conquered enemies, this time the hostile state, Macedonia, was abolished and there was no need to bring any relatives of the ruler to Rome as hostages. It is true that the family of Perseus, including the king himself, was brought to Rome, ${ }^{2}$ but not as hostages for a treaty. It is also true that the Illyrian king Gentius and other persons were brought to Rome like the son of the Thracian king Cotys ${ }^{3}$ and other persons who had been delivered to

"Lecturer (Retired), Lund University, Sweden.

1. Among the cases probably the most remarkable is the Polybios-Lexikon, see n. 30 .

2. Liv. XLV 35.1.

3. Liv. XLV 42.5. 
Perseus as hostages by Cotys. But what about the Achaeans? Where do we read about them?

Let us peruse the authors who are the likely informants. The first author to look into is of course Polybius himself. Of all the persons mentioned as hostages in Antiquity he is the only one who was an author, so his description would certainly have been interesting. What does he tell about his involuntary departure for Italy?

The books dealing with the war are rather incomplete and fragmentary but contain besides information concerning the war also the dealings in neighbouring countries but less than we would wish. Book XXVIII mentions parts of the war and the alliance between Perseus and Gentius (including mutual hostages). It also deals with conditions in Greece and among other things narrates that the Achaean Assembly in 169 B.C. on the instigation of the strategos Archon decided to support the Romans and send Polybius and other envoys to the Romans to offer help. It was declined by the Roman commander Q. Marcius Philippus, and the other envoys returned but Polybius stayed with the Romans and took part in their campaign. ${ }^{4}$ In book XXX it is mentioned that there were persons siding with Perseus in various cities, but Achaea is not especially mentioned. Embassies were sent to the Romans from various parts and among them Callicrates and others from Achaea with the aim to incriminate their countrymen for siding with Perseus, and envoys were sent by the Romans to the Achaean League to investigate the accusations. ${ }^{5}$ The sequel of the investigation is missing and we cannot follow the deportation of the Achaeans to Italy, only the hate towards Callicrates in Achaea and later the efforts of the Achaeans to retrieve the detainees in books XXX-XXXIII and the final success in book XXXV.

Of Livy's numerous books the last preserved one, book XLV, contains the end of the Macedonian war and some of its sequels, the triumph of Aemilius Paulus, the fate of Perseus and his family and that of the Thracian hostages of Perseus and the visit of the Bithynian king Prusias in Rome. But of the Achaeans nothing is said either there or in the periochae of the following books.

In the Historical Library of Diodorus Siculus book XXX contains the Macedonian war and book XXXI some of its sequels with the fate of Perseus and his family and other defeated in the war but nothing of the Achaeans.

Appianus has among his numerous narrations of the wars that the Romans conducted with the peoples and the nations around the Mediterranean of course a thorough description of the Macedonian war which comprised book XII. Unfortunately there is little preserved of this book, and although parts of the last Macedonian war are among the preserved parts, what happened after the war is not. Among the preserved part of Appianus' work Polybius is mentioned only

4. Polyb. XXVIII 12.1-6, 13.1-6, cf. XXIX 24.2.

5. Polyb. XXX 7.9, 13.3-11. 
once, and that is in the Punic war when Scipio Aemilianus and he watch the destruction of Carthago in 146 B.C. ${ }^{6}$

Strabo's History is unfortunately almost entirely lost, but in his Geography he often gives a lot of historical information. In this case he mentions only the defeat of Perseus and the destruction of cities in Epirus, ${ }^{7}$ but nothing of the sequel for the Achaeans.

Dio Cassius treats the end of the war and various sequels in book $X X$ but has nothing of the Achaeans in the preserved part. ${ }^{8}$ Only in book XXI (Zonaras 9.31) the later fate of the persons in question and the return of the survivors among the persons previously deported and the following destruction of Corinth is mentioned.

Justinus tells in book XXXIII about the Macedonian war and the capture of Perseus and his sons. Then follows a strange mix-up.The book ends with a description of how numerous Greeks were brought to Rome and detained there for a long time in spite of deputations sent to apply for them - a description that fits the Achaeans, only that Justinus instead has them to be the senators of all Aetolian towns with wives and children; an event that would have occurred more than twenty years earlier and not led to such a long detainment. Next book starts with the war against the Achaeans and the destruction of Corinth just as if it had been the immediate sequel and not occurred more than twenty years later on the other hand. Events that occurred elsewhere in the meantime are, however, told in the following. ${ }^{9}$

Among other authors biographers are among the most important, and among them, of course, Plutarchus. You could assert that most important periods of Antiquity up to the start of the Empire are covered in at least some of his biographies. In this case we should look for information in the first place in the biography of Aemilius Paulus, the victor in the Macedonian war against Perseus. But although the Macedonian war occupies a big part of the biography and includes sequels concerning the triumph and the fate of Perseus there is nothing about the Achaeans or Polybius. It would of course have been very interesting to see what was included in the biography of his son Scipio Aemilianus, Polybius' friend, but since that unfortunately belongs to the pair of biographies that is lost it cannot be studied. Among other biographies that of Cato Maior has the interesting piece of information concerning the final return of the surviving detainees.

No, it is an author of quite another kind who furnishes the details of what happened. It is Pausanias, which is not quite unexpected since he often gives detailed commentaries of events that we do not read so exhaustively in other authors, even if they should exist. Here he gives in his description of Achaea and its history the story of what happened to the Achaeans after the Macedonian

\footnotetext{
6. App. Pun. 8.132.

7. Strab. VII 7.3 (information that he has in fact taken from Polybius).

8. The fate of Perseus is given in Zonaras 9.24.

9. Cf. infra, n. 25.
} 
war. ${ }^{10}$ The Romans sent ten senators to arrange the affairs of Macedonia in the best interests of the Romans. An Achaean called Callicrates sought their favour and persuaded one of them to attend the meeting of the Achaean League. There he declared that the most influential Achaeans besides helping Perseus generally also had supplied him with money. So he required the Achaeans to condemn them to death. After their condemnation he would disclose the names of the culprits. Naturally the members protested against this unfair suggestion and demanded that the names should be mentioned before they were condemned. The Roman asserted that every Achaean who had held the office of strategos was included in the accusation since one and all had sided with the Macedonians and Perseus. Xenon, a man of great repute among the Achaeans, ${ }^{11}$ rose and said that he had served as strategos but was guilty neither of treachery to Rome nor of friendship to Perseus. Therefore he was ready to submit to trial either before the Achaeans or before the Romans. The Roman grasped the pretext, and sent for trial before the Roman court all those whom Callicrates accused of supporting Perseus, over a thousand men. In Rome no trial was made but the Romans said that they had already been condemned by the Achaeans, and distributed them throughout Etruria and its cities. ${ }^{12}$ None of them is mentioned by name, but naturally we assume that Xenon was among them even though we do not hear about him in the following or later. Polybius has given us several names of the leading Achaeans, Arcesilaus, Ariston, Stratius, Xenon, Apollonidas, Archon, Nicander and himself. ${ }^{13}$ The only one of them that we know was brought to Italy beside Polybius was Stratius. ${ }^{14}$ Polybius' father Lycortas is also mentioned among the leaders, and it is supposed that he had died before the events narrated by Pausanias.

So much for their dispatch to Italy. Nothing is said by Pausanias about hostages. ${ }^{15}$ For the following sixteen years of the Achaeans in Italy and their final return Polybius in the preserved parts of his work mentions only his own fortune and nothing about his comrades. He escaped from the fate of being dispatched to any city in Etruria or elsewhere, as we know from also other sources than Pausanias was the normal fate. Carthaginian hostages from the second Punic war

10. Paus. VII 10.7-11. Much of the wording in the narration given here is borrowed from the Loeb edition, like some resumés of other authors mentioned here.

11. Xenon from Patrae is mentioned in Polyb. XXVIII. 6.2 as one of the Achaean leaders.

12. There is a short hint of this in Polyb. XXX.32, where the senate was asked to pronounce judgment on a matter which it considered already judged by the Achaeans, whereas the Achaeans pointed out that the league had neither heard the defence of the accused nor pronounced any judgment on them and now begged the senate to see that they were put on their trial. The request, which was to no avail, is easier to understand with the long narration of Pausanias in mind.

13. Polyb. XXVIII.6.

14. See below, n. 27.

15. In fact the word 'hostage' is seldom mentioned by Pausanias at all. 
had been located in Norba, Signia, Ferentinum, Setia, Circeii and Fregellae, ${ }^{16}$ but where the hostages from the Seleucids and the Aetolians in 189 B.C. had been brought we have no information about. If any of those hostages were still located in these towns in 167 is not known. We also do not know which towns were chosen to receive the comrades of Polybius, ${ }^{17}$ but for Polybius' fate we learn from his own narrative that it was Scipio Aemilianus and his brother whose application to the Senate made it possible for him to stay in Rome. ${ }^{18}$

Perseus and his family were conducted in the triumphal procession, ${ }^{19}$ and from Livy we learn that Perseus and his son Alexander were to be brought to Alba Fucens ${ }^{20}$ and the Illyrian king Gentius who had been conquered at the same time and his family were first brought to Spoletium, and when this town refused to receive them, to Iguvium..$^{21}$ The Thracian king Cotys, who had been Perseus' ally after exchanging mutual hostages, including Cotys' son Bithys, applied for paying ransom for the hostages that had been brought to Carseoli. The Romans criticized him for having given hostages to Perseus, but in the end they returned the hostages without ransom..$^{22}$ From Plutarchus we learn that Perseus died within short, although it was not clear how, and also two of his sons; only Alexander lived on and evidently had a normal life. ${ }^{23}$

The most interesting incident in the history of hostageship during Polybius' stay in Rome was the case of the Seleucid prince Demetrius. He was the son of the elder son of Antiochus III, Seleucus, who reigned 187-175. When Seleucus died he was succeeded by his younger brother Antiochus who had been hostage in Rome, and Demetrius was sent as a hostage instead. When Antiochus died in 164, Demetrius of course expected that he would be sent back to reign as the son of Seleucus rather than Antiochus' young son. But he was denied that by the Senate and made his escape through the fact that he had his living in two places and could be absent from either without rousing suspicions. Polybius relates the story and tells that he dissuaded Demetrius from repeating his application; evidently he was himself involved in the procedure. ${ }^{24}$ The story is also related by other authors like Appian, Dio Cassius and Justinus. ${ }^{25}$ Demetrius is of course called a

16. Liv. XXXII 2.3-4, 26.5-7, 26.16-18.

17. In Polyb. XXXI.23.5 only 'the towns' are mentioned, without specification. According to Paus. VII 10.11 they were towns in Etruria.

18. Polyb. loc.cit. They were the sons of Aemilius Paulus adopted into other families. Polybius speaks at length in the following chapters of Scipio and his friendship with him.

19. Plut. Aem. XXXIII.6; XXXIV.1.

20. Liv. XLV 42.4.

21. Liv. XLV 43.9.

22. Polyb. XXX 17.1-4; Liv. XLV 42.5-11; Cass. Dio XX (Zonaras 9.24).

23. Plut. Aem. XXXVII.4; Zonaras loc.cit.

24. Polyb. XXXI.11-15. Polybius has even been thought to be the instigator of the plot, see F. W. Walbank, Polybius (Berkeley, 1972), 9.

25. App. Syr. XI 8.46-47, 67; Dio Cass. XX (Zonaras 9.25); Justinus XXXIV 3.5-9. 
hostage in this connection, but also here nobody uses that term of Polybius or sees him as a comrade of the same fortune.

During these years the Achaeans in Greece were not idle but tried several times to get their ill-fated politicians released. Unsuccessful attempts were made in 164, 159, 155 and $153 ;^{26}$ the second time Polybius mentions that the plea was made chiefly on behalf of himself and Stratius. ${ }^{27}$ The third time the plea could have been successful but that was averted by a skilful use of voting procedure by the praetor Aulus Postumius Albinus. Finally in 151 a plea was successful, when only about 300 of the original 1,000 persons were left ${ }^{28}$ and not worth a discussion whether they would be carried to their graves by bearers from Rome or from Achaea, as Cato puts it. ${ }^{29}$ Also now the word hostages is not used - Polybius speaks of $\tau \tilde{\omega} \nu \kappa \alpha \tau \varepsilon \chi 0 \mu \varepsilon \dot{v} \nu \omega \nu$ and $\tau \tilde{\omega} \nu \dot{\alpha} v \alpha \kappa \varepsilon \kappa \lambda \eta \mu \varepsilon \dot{\varepsilon} \nu \omega \nu$ (rendered with those in detention in Loeb), ${ }^{30} \tau \tilde{\omega} \nu \kappa \alpha \tau \alpha \iota \tau \iota \alpha \theta \varepsilon \dot{v} \tau \tau \omega \nu$ and $\tau \tilde{\omega} \nu \kappa \alpha \tau \eta \tau \tau \alpha \mu \varepsilon \dot{v} \nu \omega \nu$ (the accused) or $\tau \tilde{\omega} v \dot{\alpha} \kappa \lambda \eta \emptyset o u ́ v \tau \omega \nu$ (the unhappy sufferers); Plutarchus uses $\tau \tilde{\omega} v \varphi v \gamma \alpha \dot{\alpha} \delta \omega \nu$ (the exiles). Pausanias only speaks of them as the Achaeans. Only in the Loeb edition of Dio Cass XXI (Zonaras 9.31) do we find 'the survivors among their hostages', ${ }^{31}$ but it is an illusion since the Greek original has simply toù $\pi \varepsilon \varrho \iota \lambda \iota \pi \varepsilon \tilde{\varsigma} \varsigma \tau \tilde{\omega} v \dot{\alpha} v \delta \varrho \tilde{\omega} v$

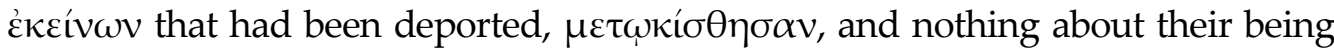
hostages.

No, certainly Polybius was not regarded as a hostage, neither by himself nor anybody else. But of course he may have felt himself like a hostage. There are many examples in Ancient literature of persons who felt or were regarded as hostages by themselves or others without strictly being so, for example daughters given in marriage for political reasons. ${ }^{32}$ Cicero speaks of his son as taken as a hostage by the state for his consulate and sees also his office, his ambition and his

26. Polyb. XXX.32, XXXII.3.14-17, XXXIII.1 3-8, 3 and 14; Walbank 1972, 10, n. 45.

27. Stratius of Tritaea was also one of the leaders mentioned in Polyb. XXVIII.6.2, see above, n. 13.

28. Paus. VII 11.12 hints that attempts of escape had been made, evidently not very successful. Dio Cass. XXI (Zonaras 9.31) tells that some of them, in despair of ever returning to their homes, made away with themselves.

29. Polyb. XXXV.6.1-4, Plut. Cato Mai. 9.3, Paus. VII.10.12. That Polybius was one of them is of course certain, but otherwise we do not know who else may have been, leaders or others.

30. Walbank speaks of internees in 1972, 75, n. 42, those summoned in 1979, 461 and detainees in 521, 542, 543 and points out in p. 461 that Mauersberger (in the Polybios-

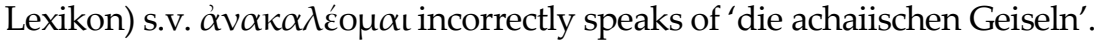

31. Translation by H. B. Baldwin \& E. Cary.

32. e.g., the daughters or nieces of Cato the Younger could be regarded as hostages when married, Plut. Cato Min. 30.3-4. 
hopes as hostages to the state. ${ }^{33}$ Lucanus lets Pompeius regard his wife as left as hostage on Lesbos during the war against Caesar. ${ }^{34}$

So with such examples in view Polybius may have felt himself as a hostage. But certainly he could not technically have been regarded so, and certainly he was not regarded as a hostage either.

\section{Bibliography}

Mauersberger, A. (Ed.) Polybios-Lexikon. (Polybios-Lexicon.) 2. Verb. Aufl. von Ch-F. Collatz, H. Helms und M. Schäfer, volume 1: 1. Berlin, 2000.

Walbank, F. W. Polybius. Sather Classical Lectures 42. Berkeley, 1972. . A Historical Commentary on Polybius, volume III. Oxford, 1979.

33. Cic. Catil. IV.2.3; Id. In Caecil. 22-72.

34. Lucan. Phars. VIII.127-133. 
